Egyptian Journal of Aquatic Biology \& Fisheries

Zoology Department, Faculty of Science,

Ain Shams University, Cairo, Egypt.

ISSN $1110-6131$

Vol. 24(7): 485 - 499 (2020)

www.ejabf.journals.ekb.eg

\title{
The natural forage base of ponds and its influence on the development of ectoparasitic invasions in the fish farms of the Lviv region, Ukraine
}

\section{Loboiko Yurii ${ }^{1 *}$, Barylo Yevheniia ${ }^{1}$, Barylo Bohdan $^{1}$, Dumych Oksana $^{2}$, Mohamed Keznine ${ }^{3}$ and Hassan Benaissa ${ }^{4}$}

1-Stepan Gzhytskyi National University of Veterinary Medicine and Biotechnologies Lviv, Pekarska str., 50,

Lviv, 79010, Ukraine,

2-Ivan Franko National University of Lviv 4, Hrushevskyi St., Lviv 79005, Ukraine,

3-Faculty of Science, Abdelmalek Essaadi University, Tetouan, Morocco.

4- Faculty of Science, Cadi Ayad University, Marrakech, Morocco

*Corresponding Author: y.bachuk.lv@gmail.com

\section{ARTICLE INFO}

Article History:

Received: Sept. 4, 2020

Accepted: Oct. 30, 2020

Online: Nov. 7, 2020

\section{Keywords:}

Fish farm,

Lernaea cyprinacea,

Dactylogyrus vastator,

Cladocera,

Copepoda ,

Lviv region,

zoobenthos.

\section{ABSTRACT}

The investigated reservoirs of fish farms, 76 taxonomic units of zooplankton, represented by colloquials (Rotatoria) and crustaceans (Crustacea), have been identified. As part of the dominant complex, representatives of the genera Asplanchna, Brachionus (Rotatoria), Ceriodaphnia, Daphnia (Cladocera), Acanthocyclops, Eudiaptomus (Copepoda) prevailed. During May to September, indicators of zooplankton development were 118.73-348.37 thousand ind. $/ \mathrm{m}^{3}$ - by number and $6.08-9.95 \mathrm{~g} / \mathrm{m}^{3}$ - by biomass.The basis of phytoplankton was consisted of green, diatoms, eugenic and blue-green algae with predominance of the genera Scenedesmus, Euglena, Navicula, Pediastrum, Peridinium, Oscillatoria, Microcystis. The average seasonal values of phytoplankton fluctuated within the limits of 39.15-169.87 million cells $/ \mathrm{dm}^{3}$ - by the number and $4.69-13.86 \mathrm{mg} / \mathrm{dm}^{3}-$ for biomass. Zoobenthos of the studied reservoirs are represented by larvae of chironomidae and oligochaetae. The average seasonal numbers of zoobenthos in the ponds of the farms were in the range of $246.05-367.18$ ind. $/ \mathrm{m}^{2}$, biomass $1.74-1.92 \mathrm{~g} / \mathrm{m}^{2}$.

According to the results of the epizootic monitoring in the fish farms of the Lviv region, the invasiveness of the carp by ectoparasites Lernaea cyprinacea and Dactylogyrus vastator is established. The disease was recorded as mono- and associative invasions. The extensiveness of the invasion (of yearlings carp lernaea in the growing ponds was $10-35 \%$ (intensity of invasion - 1.67-3.43 sp.), dactylogyruses - 10-50\% (II - 4.2-11.6 sp.). Mixed invasion L. cyprinacea and D. vastator are found in $20-35 \%$ of yearlings carp (II lernaea - 1.75-2.83 sp., dactylogyruses - 6.75-11.33 sp.). The highest invasibility of yearlings carp with ectoparasites in the ponds was established during July-August.

\section{INTRODUCTION}

The invasive fish diseases are widespread in water bodies of Ukraine and cause significant economic losses. They can manifest differently, in particular, pathological changes in the body can lead to death, latent disease, growth and development delay and decreased productivity of fish (Vovk, 2002; Rastiannasab et al., 2016; Golzio et al., 2017). One of the reasons hampering the development of fish farming and increasing fish productivity is ectoparasitic because of these fish diseases (Hemaprasanth et al., 2011; Loboiko, 2012; Benovics et al., 2017).

The importance of ichthyoparasitological measuremen is because it studies the overall range of veterinary activities and the increasing connection with the development of fisheries and introduction of new fish farming facilities. Obviously, an objective diagnosis of an invasive disease can only be established by determining the species of its pathogen. Only after diagnosis can the 
high efficiency of prevention and treatment be achieved and, as a consequence, a reduction in fisheries losses (Abdullaev, 2011; Hossain et al., 2018).

In recent years Ukrainian ponds have became widespread with outbreaks of such invasive fish diseases. Such as botriocephalosis, caviosis, dactylogyrus, hydrodactylosis, argulosis, lerneosis, to name a few have become widespread in many fisheries in Ukraine, especially in flocks (Beliba, 2006; Pukalo, 2006; Jmil and Jmil, 2010; Gemmerday, 2010; Mazur et al., 2011; Yevtushenko, 2013; Nitta and Nagasawa, 2017). Therefore, the purpose of our research was to investigate the epizootic situation of the spread of the ectoparasitic invasion of Lernaea cyprinacea and Dactylogyrus vastator and the impact it has on the natural forage base of ponds.

\section{MATERIALS AND METHODS}

To find out the effect of the hydrobiological regime of ponds on the invasiveness of lerneosis and dactylogyrus of carp in ponds: "Rudniki" (1), "Velykyi Lyubin" (2), "Stryi" (3), "Khodoriv" (4) carried out monthly hydrobiological studies during the growing season.

When conducting hydrobiological studies, the samples were taken according to conventional methods in hydrobiology (Abakumov, 1983; Kiselov, 1969): water was pumped with a $1 \mathrm{dm} 3$ Rutner bathometer 50 times at each of three stations of sampling points and filtered through an Apstein (gas №72) net to which was attached a $33.5 \mathrm{ml}$ metal beaker. The selected sample was fixed with $4 \%$ formalin solution. Qualitative samples were processed on the same day no later than 2-3 hours after the selection procedure. Quantitative calculation of the collected material was performed in Bogorov's chamber. Taxonomic identification of species was performed according with (Manuylova, 1964; Kutikova, 1970; Monchenko, 1974), as well as using other sources, the size of individuals was determined by living and fixed material and using literary data.

Zooplankton biomass was calculated by equating individual shapes to simple geometric figures whose volumes were taken from nomograms to determine the mass of aquatic organisms (Chislenko, 1968). In some species of rotifers and crustaceans, the mass of individuals was determined based on the dependence of body length on mass (Balushkina and Vinberg, 1979; Vinberg and Lavrentieva, 1982).

To assess the species similarity of zooplankton and establish the level of organic contamination of the studied reservoirs, the Chekanovsky-Sörensen similarity index and the PantleBuck saprobity index were used, respectively.

The similarity coefficient of the species composition of reservoirs $(\mathrm{K})$ was calculated by the formula to (Sörensen, 1948):

$$
K=\frac{2 \times C}{A+B} \times 100 \%
$$

where $\mathrm{A}$ and $\mathrm{B}$ - the number of species in the two compared lists;

$\mathrm{C}$ - the number of common species.

Calculation of saprobity was performed by the Pantle-Buck method in the modification of Sladeček (1973).

Indicative significance $(S)$ of the species was taken based on their saprobity valences reported in Sladeček (1973). The formula for calculating the saprobity index: 


$$
S=\frac{S \times n}{n}
$$

Where : $\mathrm{S}$ : is the total saprobity index;

$\mathrm{s}:$ the indicator significance of the species;

$\mathrm{n}$ : the absolute number of the species.

At the same time, we studied the epizootic situation regarding the spread of lerneosis and dactylogyrus in the ponds of fisheries in the Lviv region: "Khodoriv", "Rudniki", " Stryi", and ponds of the "Velykyi Lyubin", where they grow fish by modern technology. The carp yearlings (Cyprinus carpio L.) were examined.

Ichthyoparasitological analysis was performed by the method of incomplete parasitological dissection by Bykhovskaya-Pavlovskaya (1985).

Parasites species were determined by «The determinant of parasites of freshwater fish of the fauna of the USSR» (Bauer, 1987). The magnitude of the invasion (EI) was determined by the following relationship:

$$
E I=\frac{x}{y} \times 100
$$

Where: $\mathrm{x}$ : the number of fish in which the parasites were detected;

$y:$ the total number of fish tested.

The invasion intensity (II) was determined by counting the number of parasites on the body and gills of the fish studied.

\section{RESULTS AND DISCUSSION}

In the shallow areas of the growing ponds, which are the most productive parts of reservoirs, due to the formation of a large amount of detritus of different origin and the intensive development of bacteria, there was discovered a large number of living organisms. One of the components of aquatic biocenoses is zooplankton organisms that inhabit the water column and are exceptionally rich in both qualitative and quantitative grouping (Arsan et al., 2006).

It was found that 76 taxonomic units of zooplankton belonging to three systematic groups were identified in the studied reservoirs: lower worms of the Rotatoria class and crustaceans of Cladocera suborder and Copepoda order. Among the identified aquatic species, 36 species are in the Rotatoria class, accounting for $47.37 \%$ of the total species. Of the Cladocera crustaceans, 24 species $(31.58 \%)$ were identified, and the least Copepoda species - 16 species $(21.05 \%)$. Species found are mainly pond forms that can occur in rivers and lakes. They withstand significant changes in environmental factors, including significant fluctuations in temperature and $\mathrm{pH}$, some of which are resistant to high levels of dissolved oxygen and organic matter. The most represented were the genera Asplanchna, Brachionus (Rotatoria); Ceriodaphnia, Daphnia (Cladocera), Acanthocyclops, Eudiaptomus (Copepoda).

The following species were found in all ponds of the farms: Asplanchna priodonta, Brachionus angularis, B.calyciflorus, B.diversicornis, B.quadridentatus, Filinia longiseta, Keratella cochlearis, K.quadrata, Lecane luna, Polyarthra vulgaris, Alona rectangula, Bosmina 
longirostris, Ceriodaphnia pulchella, Chydorus sphaericus, Daphnia magna, D. pulex, Diaphanosoma brachyurum, Acanthocyclops americanus, Mesocyclops leucrarti, Thermocyclops crassus, Diaptomus castor.

The dynamics of zooplankton density is determined mainly by the development of rotifers, and the biomass by the development of crustaceans Cladocera and Copepoda which was characteristic of all ponds. The ratio of Rotatoria: Cladocera: Copepoda is volatile and depends on the specificity of the reservoir. The most represented genera among rotifers were: Asplanchna, Brachionus.

During the study period study were registered 53 species of zooplankton in the growing pond of the farm "Rudniki" (Table 1). The dominant groups of pond zooplankton in May were cladocerans and nauplial stages of the copepods.

The immature stages of the crustaceans - Nauplia dominated (with a D index of $>50 \%$ ). The complex of the most numerous species is represented mainly by the pelagobionts Brachionus calyciflorus, B.falcatus, Keratella cochlearis, K.quadrata, Polyarthra vulgaris, Pompholyx sulcata and eurytopic (Bosmina longirostris and Daphnia magna) crustaceans. The high biomass values for May were established due to the development of large-scale daphnia during the period of late May - early June.

Table 1: Quantity (N, thous.ind. $\left./ \mathrm{m}^{3}\right)$ and biomass $\left(\mathrm{B}, \mathrm{g} / \mathrm{m}^{3}\right)$ of zooplankton in the growing pond of the "Rudniki" farm

\begin{tabular}{|l|l|l|l|l|l|}
\hline month & V & VI & VII & VIII & IX \\
\hline $\mathbf{N}$ & $\sum=643.667$ & $\sum=239.656$ & $\sum=116.44$ & $\sum=98.517$ & $\sum=324.78$ \\
& $\mathrm{Ro}=10.762$ & $\mathrm{Ro}=1.703$ & $\mathrm{Ro}=4.806$ & $\mathrm{Ro}=1.594$ & $\mathrm{Ro}=5.34$ \\
& $\mathrm{Cl}=529.361$ & $\mathrm{Cl}=165.942$ & $\mathrm{Cl}=54.481$ & $\mathrm{Cl}=76.636$ & $\mathrm{Cl}=209.00$ \\
& $\mathrm{Co}=103.544$ & $\mathrm{Co}=72.011$ & $\mathrm{Co}=57.153$ & $\mathrm{Co}=20.287$ & $\mathrm{Co}=110.44$ \\
\hline $\mathbf{B}$ & $\sum=11.576$ & $\sum=12.138$ & $\sum=3.3509$ & $\sum=9.723$ & $\sum=6.502$ \\
& $\mathrm{Ro}=0.0094$ & $\mathrm{Ro}=0.003$ & $\mathrm{Ro}=0.045$ & $\mathrm{Ro}=0.0004$ & $\mathrm{Ro}=0.004$ \\
& $\mathrm{Cl}=10,392$ & $\mathrm{Cl}=8.062$ & $\mathrm{Cl}=2.069$ & $\mathrm{Cl}=8.497$ & $\mathrm{Cl}=5.1870$ \\
& $\mathrm{Co}=1.175$ & $\mathrm{Co}=4.073$ & $\mathrm{Co}=1.348$ & $\mathrm{Co}=0.226$ & $\mathrm{Co=1.311}$ \\
\hline
\end{tabular}

Short-term development of D. magna occurred under appropriate trophic and temperature conditions. During this period, under favorable temperature conditions, the reservoirs were fertilized with mineral and organic fertilizers, which led to an increase in the amount of organic matter in the water and stimulated the development of D. magna due to sufficient feed resources.

The diversity of zooplankton fauna depends on the hydrochemical regime. It is known that low values of oxygen content in the water cause the appearance of small-sized species, which was 
observed in the pond at the end of the growing season. The accumulation of organic matter has contributed to the accelerated development of mesosaprobic organisms that are resistant to significant concentrations of organic matter in the reservoir and are numerous in these conditions (Keratella cochlearis, Bosmina longirostris).

Hydrobionts are mainly represented by pond phytophylic and coastal phytophilic species, including Euchlanis dilitata, Alona rectangula, Diaphanosoma brachyurum, Chydorus sphaericus, Eucyclops serrulatus, typical pelagic forms Daphnia longispina, Leptodora kindtii. Registered as representatives of the potamophilic complex - Brachionus angularis, B.calyciflorus, Keratella quadrata, Bosmina longirostris, and limnophilic - Asplanchna priodonta, Brachionus diversicornis, B.quadridentatus, Filinia longiseta, Keratella cochlearis, Polyarthra vulgaris. Zooplankton communities were dominated by Daphnia magna, D. longispina, D. pulex, D. longirostris, Ceriodaphnia quadrangula, Diaptomus sp. and immature stages of copepods.

The development of zooplankton in ponds was determined by Cladocera, which prevailed both in numbers and in biomass. These include, in particular, Bosmina longirostris, Daphnia magna, D. pulex, Ceridaphnia quadrangula. Zooplankton decrease was observed in June (Table 1). This situation has arisen, obviously, for several reasons. The transition from spring to summer is characterized by depression in the development of zooplankton, which is manifested in a decrease in the number of cladocereans, in particular large Daphnia. In May, the number of representatives of the genera Bosmina, Daphnia, Ceriodaphnia in the composition was 18.34-296.82 thousand individuals $/ \mathrm{m} 3$, which was respectively $5.7-36.4 \%$ of the total number of zooplankton, in June the number of these representatives of Cladocera, including Daphnia, decreased to 8.4-20.18 thousand individuals $/ \mathrm{m}^{3}$, only several individuals of Ceriodaphnia and Bosmina were registered.

Another reason for the decrease in the number of zooplankton in June was due to its active eating of fish. This explains the disappearance of small representatives of the species Bosmina longirostris and other crustaceans from zooplankton. The high values of zooplankton biomass were due to the small number of large sized Daphnia and adult stages of copepods.

In general, the natural forage base found in the ponds was satisfactory. Throughout the growing season, the minimum biomass value did not decrease below the regulatory limit of 3.35 $\mathrm{g} / \mathrm{m}^{3}$ for the ponds cultivation type under study. Throughout the period, the largest contribution to biomass was due to Cladocera, and only in August, except for the Cladocera, a significant proportion of zooplankton biomass accounted for the Copepoda, and in September the lower crustaceans also played a significant role in fodder.

In the pond, along with the cladocereans, copepods reached the essential development, although they did not play a significant role in the total biomass of zooplankton. The average seasonal biomass of zooplankton during the growing season was $8.658 \mathrm{~g} / \mathrm{m}^{3}$, which is within the normal range for the area. It would be expected more reduction in the abundance of zooplankton, especially large species, due to fish-eating, but obviously the investigated ichthyofauna was looking for other feed, in particular larger-sized benthic organisms.

The zooplankton of the growing stock of the "Velykyi Lyubin" was represented by 51 taxonomic units (Table 2). 
Table 2 : The number (N, thousand individuals $/ \mathrm{m3})$ and biomass $\left(\mathrm{B}, \mathrm{g} / \mathrm{m}^{3}\right)$ of zooplankton in the growing stock of the "Velykyi Lyubin"

\begin{tabular}{|l|l|l|l|l|l|}
\hline month & V & VI & VII & VIII & IX \\
\hline $\mathbf{N}$ & $\sum=684.385$ & $\sum=128.067$ & $\sum=134.128$ & $\sum=438.267$ & $\sum=356.986$ \\
& $\mathrm{Ro}=4.202$ & $\mathrm{Ro}=0.67$ & $\mathrm{Ro}=5.621$ & $\mathrm{Ro}=40.151$ & $\mathrm{Ro}=2.291$ \\
& $\mathrm{Cl}=439.011$ & $\mathrm{Cl}=67.914$ & $\mathrm{Cl}=52.381$ & $\mathrm{Cl}=126.831$ & $\mathrm{Cl}=99.942$ \\
& $\mathrm{Co}=241.172$ & $\mathrm{Co}=59.483$ & $\mathrm{Co}=74.126$ & $\mathrm{Co}=271.285$ & $\mathrm{Co}=254.753$ \\
\hline $\mathbf{B}$ & $\sum=9.931$ & $\sum=7.715$ & $\sum=4.376$ & $\sum=16.948$ & $\sum=10.804$ \\
& $\mathrm{Ro}=0.011$ & $\mathrm{Ro}=0.001$ & $\mathrm{Ro}=0.008$ & $\mathrm{Ro}=0.091$ & $\mathrm{Ro}=0.007$ \\
& $\mathrm{Cl}=7.562$ & $\mathrm{Cl}=5.633$ & $\mathrm{Cl}=2.741$ & $\mathrm{Cl}=13.431$ & $\mathrm{Cl}=6.399$ \\
& $\mathrm{Co}=2.358$ & $\mathrm{Co}=2.081$ & $\mathrm{Co}=1.627$ & $\mathrm{Co}=3.426$ & $\mathrm{Co}=4.401$ \\
\hline
\end{tabular}

$* \sum$ - total number; Ro, $\mathrm{Cl}, \mathrm{Co}-$ the number of Rotatoria, Cladocera, Copepoda respectively.

21 taxa of rotifers (Rotatoria), cladocereans - 16, copepods - 14 were registered. All major zooplankton groups were uniformly represented by pond phytophylic and coastal-phytophilsc species and by pelagic, potomophilic and limnophilic forms.

Dominants in zooplankton groups were in May; Bosmina longirostris, Daphnia pulex, Polyphemus pediculus, immature copepods; in June - Daphnia pulex, D. magna, Diaptomus sp., immature forms of copepods; in July - Daphnia pulex, D. magna, D. longispina, immature forms of copepods; in August - Daphnia pulex, D. magna, D. longispina, Acanthocylops americanus, Thermocyclops crassus, copepod stages of Copepoda.

Feed base at the beginning of the growing season was satisfactory. The groups of crustaceans (Table 2), mainly cladocereans, were the basis of the grouping by number and biomass, and copepods began to play an important role in the structure of zooplankton from the second half of the growing season. It is known that the quantitative development of forage zooplankton, and in the first place immediately after the ponds are stocked, depends, in addition to the state of their bed, also on the abundance of zooplankton ponds that enters these ponds with the water that flows into them. After pouring ponds the picture turned out to be this: in May, the number of zooplanktons was 684.39 thousand $/ \mathrm{m}^{3}$, biomass $-9.93 \mathrm{~g} / \mathrm{m}^{3}$. The predominants were small crustaceans - Bosmina longirostris (Cladocera) and the nauplial and copepodit stages of the copepods. The largest decline in the development of zooplankton was observed in the second half of June, when the number decreased by 5 times (up to 128.10 thousand units $/ \mathrm{m}^{3}$ ) and in July $\left(134.128\right.$ thousand units $/ \mathrm{m}^{3}$ ).

It should be noted that the small-sized cladocera of the Bosmina genus and the immature stages of the copepods, which were the absolute dominant in May, were reported to be extremely small, in contrast to the larger-sized zooplankton species - representatives of the genus Diaptomus and genus Daphnia. Many authors have noted a sharp decrease in zooplankton in the middle of summer, in our case this situation was observed in the second half of June.

In the second half of July, there was an increase in the number of zooplankton, which lasted until the end of the growing season. Biomass indicators have the same tendency. There have been changes in the structure of zooplankton. If in June the number of species did not exceed 10 and the dominant were mature and smaller by 2-3 times the size of the individual Daphnia, in particular Daphnia pulex and D. magna, in July the number of species of zooplankton increased to 15 , but 
already dominated by less than Daphnia-sized and copepodite stages of copepods, which did not yield a 2-fold increase in biomass. However, by the end of July, the situation with the forage base had improved significantly and in August biomass reached its maximum value $-16.95 \mathrm{~g} / \mathrm{m}^{3}$.

In September, biomass declined slightly due to the increase in the number of microplankton, in particular rotifers, which had a significant number and small individual weights, compared to crustaceans, which did not make a significant contribution to the total zooplankton biomass, and Cladocera were small in size.

The dynamics of zooplankton development in the pond was characterized by the decline of one in numbers in June and a decrease of one in biomass in July, followed by a gradual increase in numbers and biomass. In general, the quantitative indices of zooplankton development were within the normal range for growing ponds of the forest-steppe zone, as evidenced by the average seasonal indicators, which amounted to $9,955 \mathrm{~g} / \mathrm{m}^{3}$. The hydrochemical composition of the water was not a limiting factor for the development of zooplankton, as the chemical parameters were generally within the normal range.

In the study of zooplankton, 42 taxa of zooplankton organisms were identified in the cultivation pond of the Khodoriv farm, 21 of them related to Rotatoria, 14 to Cladocera, 10 to Copepoda (Table 3).

Table 3: The number $(\mathrm{N}$, thousand individuals $/ \mathrm{m3})$ and biomass $\left(\mathrm{B}, \mathrm{g} / \mathrm{m}^{3}\right)$ of zooplankton in the cultivation pond of the Khodoriv farm

\begin{tabular}{|c|l|l|l|l|l|}
\hline month & \multicolumn{1}{|c|}{$\mathrm{V}$} & \multicolumn{1}{|c|}{ VI } & \multicolumn{1}{c|}{ VII } & \multicolumn{1}{c|}{ VIII } & \multicolumn{1}{c|}{ IX } \\
\hline $\mathbf{N}$ & $\sum=409.03$ & $\sum=52.846$ & $\sum=89.927$ & $\sum=103.213$ & $\sum=485.808$ \\
& $\mathrm{Ro}=1.214$ & $\mathrm{Ro}=0.652$ & $\mathrm{Ro}=3.902$ & $\mathrm{Ro}=16.657$ & $\mathrm{Ro}=129.253$ \\
& $\mathrm{Cl}=371.66$ & $\mathrm{Cl}=47.421$ & $\mathrm{Cl}=27.241$ & $\mathrm{Cl}=38.671$ & $\mathrm{Cl}=119.281$ \\
& $\mathrm{Co}=36.16$ & $\mathrm{Co}=4.763$ & $\mathrm{Co}=58.784$ & $\mathrm{Co}=47.885$ & $\mathrm{Co}=237.274$ \\
& $\sum=6.566$ & $\sum=4.896$ & $\sum=3.347$ & $\sum=4.117$ & $\sum=12.099$ \\
& $\mathrm{R} 0=0.012$ & $\mathrm{Ro}=0.001$ & $\mathrm{Ro}=0.006$ & $\mathrm{Ro}=0.031$ & $\mathrm{Ro}=0.362$ \\
& $\mathrm{Cl}=6.061$ & $\mathrm{Cl}=4.604$ & $\mathrm{Cl}=2.326$ & $\mathrm{Cl}=3.208$ & $\mathrm{Cl}=8.026$ \\
& $\mathrm{Co}=0.493$ & $\mathrm{Co}=0.291$ & $\mathrm{Co}=1.015$ & $\mathrm{Co}=0.878$ & $\mathrm{Co}=3.711$ \\
\hline
\end{tabular}

* $\sum$ - total number; Ro - is the number of rotifers, $\mathrm{Cl}$ - is Cladocera, Co - is Copepoda.

Hydrobionts were represented mainly by phytophylic and coastal phytophilic species, in particular Euchlanis dilitata, Alona rectangula, Diaphanosoma brachyurum, Chydorus sphaericus, Eucyclops serrulatus, Macrocyclops albidus, also typical pelagic forms Daphnia longispina, Leptodora kindtii. Registered as representatives of the potamophilic complex - Brachionus angularis, B.calyciflorus, Keratella quadrata, Bosmina longirostris, and limnophilic - Asplanchna priodonta, Brachionus diversicornis, B.quadridentatus, Filinia longiseta, Keratella cochlearis, Polyarthra vulgaris. Quantitative development of zooplankton was low, but was within normal limits. During the season, numbers and biomass fluctuated accordingly 52.84-485.81 thousand ind. $/ \mathrm{m}^{3}$ and $3.347-12.099 \mathrm{~g} / \mathrm{m}^{3}$.

The general trend of zooplankton dynamics showed a decrease in numbers and minimum values in June-July, which is explained by the eating of zooplankton by adult small fish and some growth in late July-August. In particular, the higher values of zooplankton in the third decade of 
May amounted to 485.82 thousand ind.$/ \mathrm{m}^{3}$ (due to the development of Bosmina longirostris and the presence of nauplial stages of paddlefish) and within a month the number of zooplankton decreased to 52.84 thousand ind. $/ \mathrm{m}^{3}$ (9 times), which indicates that fish stocks are fully utilized.

In July, there was a slight increase in zooplankton due to rotifers and immature stages (nauplial and copepodite) of copepods. As for this year rotifers do not play a significant role in the forage base, so their development could not significantly affect the size of the forage base. For the more caloric lower crustaceans, they did not show significant development and in the period JulyAugust their numbers fluctuated within 27.241-38.671 (Cladocera) and 47.885-58.784 (Copepoda) thousand ind. $/ \mathrm{m}^{3}$. In general, the biomass analysis of zooplankton communities has shown the following. Its values were low and varied from 3.347 to $12.099 \mathrm{~g} / \mathrm{m}^{3}$. The average seasonal zooplankton was $6.205 \mathrm{~g} / \mathrm{m}^{3}$, which is within the normative range for the given zone $\left(3-10 \mathrm{~g} / \mathrm{m}^{3}\right)$.

Maximum biomass values accounted for the period of relatively significant development of zooplankton in May, when biomass was $6.566 \mathrm{~g} / \mathrm{m}^{3}$. During May-June, the major contribution to biomass was made by Cladocera, in July and August a significant role in biomass production also belonged to Copepoda and partially rotifers, although no significant difference was found between the three zooplankton groups during this period. Similarly, in June, biomass also declined, and in July, as the population grew (due to zooplankton restructuring, rotifers began to dominate), biomass continued to decline. At the end of the growing season, there was an outbreak of zooplankton development in all three groups - Rotatoria, Cladocera, Copepoda.

The zooplankton of the Stryi farm was represented by 45 taxonomic units (Table 4)

Table 4: The number (N, thousand individuals $\left./ \mathrm{m}^{3}\right)$ and biomass $\left(\mathrm{B}, \mathrm{g} / \mathrm{m}^{3}\right)$ of zooplankton in the cultivation pond of the Stryi farm

\begin{tabular}{|l|l|l|l|l|l|}
\hline month & V & VI & VII & VIII & IX \\
\hline \multirow{4}{*}{$\mathbf{N}$} & $\sum=85.227$ & $\sum=38.053$ & $\sum=44.346$ & $\sum=93.215$ & $\sum=332.829$ \\
& $\mathrm{Ro}=4.156$ & $\mathrm{Ro}=1.237$ & $\mathrm{Ro}=7.513$ & $\mathrm{Ro}=1.487$ & $\mathrm{Ro}=12.341$ \\
& $\mathrm{Cl}=77.128$ & $\mathrm{Cl}=19.775$ & $\mathrm{Cl}=28.437$ & $\mathrm{Cl}=72.465$ & $\mathrm{Cl}=211.026$ \\
& $\mathrm{Co}=3.943$ & $\mathrm{Co}=17.041$ & $\mathrm{Co}=8.396$ & $\mathrm{Co}=19.263$ & $\mathrm{Co}=109.462$ \\
\hline \multirow{4}{*}{ B } & $\sum=10.778$ & $\sum=1.652$ & $\sum=2.328$ & $\sum=6.543$ & $\sum=9.089$ \\
& $\mathrm{Ro}=0.003$ & $\mathrm{Ro}=0.0006$ & $\mathrm{Ro}=0.005$ & $\mathrm{Ro}=0.0008$ & $\mathrm{Ro}=0.0035$ \\
& $\mathrm{Cl}=10.713$ & $\mathrm{Cl}=1.483$ & $\mathrm{Cl}=2.284$ & $\mathrm{Cl}=5.213$ & $\mathrm{Cl}=8.761$ \\
& $\mathrm{Co}=0.062$ & $\mathrm{Co}=0.168$ & $\mathrm{Co}=0.039$ & $\mathrm{Co}=1.329$ & $\mathrm{Co}=0.324$ \\
\hline
\end{tabular}

$* \sum$ - total number; Ro - is the number of rotifers, $\mathrm{Cl}$ - is Cladocera, Co - is Copepoda.

According to the results of the research, the values of zooplankton development in the growing pond varied within: in the amount of 38.053-332.829 thousand ind. $/ \mathrm{m}^{3}$, in biomass $1.652-10.778 \mathrm{~g} / \mathrm{m}^{3}$. The average seasonal zooplankton was $6.078 \mathrm{~g} / \mathrm{m}^{3}$.

21 taxa, Cladocera - 14, Copepoda - 10 were recorded in the Rotatoria. The faunal composition of the study group consisted mainly of the littoral and pelagic forms of pond, potamophilic and limnophilic zooplankton. In the growing pond of the farm "Stryi" the number of individuals increased from May to August.

In May and June, low values of dissolved oxygen content and a high $\mathrm{pH}$ level limited the development of Rotatoria to their near complete disappearance from zooplankton groups. Eating by 
fish larvae stages the populations of rotifers has reduced their numbers to a minimum. In this pond, much overgrown with vegetation, the littoral forms of Rotatoria became more numerous. The subsequent decrease in $\mathrm{pH}$, the increase of oxygen content in water stimulated the development of zooplankton. The increasing amount of organic matter, which usually leads to an increase in microflora, has contributed to the development of bacteriophages. This increase in its total content had a positive effect on the number of rotifers and led to the development of small-sized species: Keratella tropica, K. cochlearis, Pompholyx sulcata, Brachionus angularis, B. calyciflorus, B. diversicornis, Asplanchna girodi, A. priodonta; the basis of the population of Cladocera was $B$. longirostris. It should be noted that a sharp decrease in the number of B. Longirostris and small rotifers was observed under the high number of elder copepodite stages of the copepods. The increase in organic matter content in ponds had a positive effect on the development of Rotatoria.

In the phytoplankton, the largest number of species are represented by greens, diatoms, eugenic, blue-green algae. The most numerous were the genera: Scenedesmus Meyen, Euglena Ehrb., Navicula Bory, Pediastrum Meyen, Peridinium Ehrb, Oscillatoria Vauch, Microcystis Lem. According to the research results, phytoplankton development rates in experimental ponds of fisheries varied within the range of $0.16-549.48 \mathrm{million} \mathrm{cl} / \mathrm{dm}^{3}$, and of biomass $-0.06-40.12$ $\mathrm{mg} / \mathrm{dm}^{3}$. The increase of biomass values from the beginning to the end of the period of fish cultivation is established.

During the growing season, one, two or three "blooms" of water were recorded, among the reasons of which was the increase in the content of biogenic elements and allochthonous organic matter in the ponds. It caused "flowering" water mainly by Oocystis borgei, Melosira granulata. The increase in the intensity of phytoplankton development was also explained by changes in the processes of mineralization of organic matter by microorganisms during the year, since both phytoplankton and bacterioplankton ponds are characterized by a gradual increase in numbers by the end of the growing season with the maximum development in August-September during the same period. The average seasonal values of phytoplankton were: in size - 39.15-169.87 million $\mathrm{cl} / \mathrm{dm}^{3}$ in biomass $-4.69-13.86 \mathrm{mg} / \mathrm{dm}^{3}$.

Development of zoobenthos organisms varied in the studied reservoirs within: 24.78-674.31 ind. $/ \mathrm{m}^{2}$ by number and $0.17-4.63 \mathrm{~g} / \mathrm{m}^{2}$ by biomass. The maximum values of the biomass of bottom fodder organisms were recorded in June $-4.06-4.27 \mathrm{~g} / \mathrm{m}^{2}$. During this period, chironomidae larvae accounted for $82-98 \%$ of the total quantitative values of zoobenthos. In the future, the data gradually decreased to the minimum values in August, which is related to the seasonal dynamics and eating of benthic organisms by carp yearlings (Table 5).

Table 5: Dynamics of development of zoobenthos in ponds of the studied farms ( $\mathrm{N}\left(\mathrm{ind} . / \mathrm{g} / \mathrm{m}^{2}\right), \mathrm{B}$ $(\mathrm{g} / \mathrm{m} 2)$

\begin{tabular}{|l|l|l|l|l|}
\hline $\begin{array}{l}\text { Groups of } \\
\text { organisms }\end{array}$ & Values & June & July & August \\
\hline \multirow{2}{*}{ Chironomidae } & $\mathrm{N}$ & $497.46-548.81$ & $149.76-162.13$ & $21.34-27.06$ \\
\cline { 2 - 5 } & $\mathrm{B}$ & $3.78-4.19$ & $1.26-1.46$ & $0.09-0.12$ \\
\hline \multirow{2}{*}{ Oligochaeta } & $\mathrm{N}$ & $64.43-68.12$ & $117.96-119.68$ & 0.00 \\
\cline { 2 - 5 } & $\mathrm{B}$ & $0.02-0.04$ & $0.11-0.14$ & 0.00 \\
\hline \multirow{2}{*}{ Others } & $\mathrm{N}$ & $49.84-55.03$ & $63.57-66.21$ & $59.87-64.13$ \\
\cline { 2 - 5 } & $\mathrm{B}$ & $0.02-0.03$ & $0.01-0.2$ & 0.00 \\
\hline
\end{tabular}


The average seasonal values of zoobenthos in ponds of farms were $246.05-367.18 \mathrm{ind} . / \mathrm{m}^{2}$, biomass - 1.74-1.92 $\mathrm{g} / \mathrm{m}^{2}$. The basis of zoobenthos biomass in all ponds was formed by chironomidae larvae (95-97\%).

In general, values of quantitative development of the components of the natural forage base met the standards for the growing ponds of the forest-steppe zone of Ukraine and as we consider, were not a brake factor for the development of farmed fish.

Assessment of the sanitary status of reservoirs was carried out by zooplankton organisms. According to the list of indicator species (Sladeček, 1973), 64 indicator species have been identified in the studied reservoirs during the observations. In the ponds of fishery farms "Rudniki", "Velykyi Lyubin", "Stryi", "Khodoriv" respectively revealed 6, 5, 5, 5; o- $\beta$-mesosaprobes - 12, 8, 9 , 10 ; $\beta$-mesosaprobes - 15, 16, 11,12; $\beta$-o-mesosaprobes - 6, 6, 6, 5; $\beta$ - $\alpha$-mesosaprobes - 4, 6, 5, 6; $\alpha$ mesosaprobes - 1, 1, 2, 1; $\alpha$-p-mesosaprobes - 2, 2, 1, 1 .

In farm ponds, Pantle-Buck index values ranged as 1.6-3.3 (pond 1), 1.5-2.1 (pond 2), 1.42.2 (pond 3) (Table 6).

Table 6: Dynamics of Pantle-Buck saprobity index by zooplankton organisms in ponds

"Rydnyky" (1), "Velykyi Lyubin" (2), "Stryi" (3), "Khodoriv" (4)
\begin{tabular}{|l|l|l|l|l|}
\hline Month & Pond 1 & Pond 2 & Pond 3 & Pond 4 \\
\hline May & 1.8 & 1.7 & 2.0 & 1.8 \\
\hline June & 2.3 & 2.1 & 2.9 & 2,6 \\
\hline July & 1.6 & 1.9 & 1.7 & 2.0 \\
\hline August & 1.9 & 1.8 & 2.0 & 1.9 \\
\hline September & 2.0 & 2.2 & 2.6 & 2,8 \\
\hline
\end{tabular}

High index values in May-June were driven by the prevailing development Brachionus angularis $(\beta-\alpha-$ mesosaprobes), B. calyciflorus $(\beta-\alpha-)$, Filinia longiseta $(\beta-\alpha-)$ and Daphnia magna $(\alpha-p-)$. At the end of the growing season in August-September, due to increased recovery processes in the water increased the number of Asplanchna priodonta (o- $\beta-)$, Brachionus calyciflorus $(\beta-\alpha), B$. falcatus $(\beta-), B$. diversicornis $(\beta-)$, Filinia longiseta $(\beta-\alpha-)$, Keratella tropica $(\beta-)$. Unconditional dominance here of populations of Cladocera Bosmina longirostris and rotifers Brachionus falcatus, Keratella reducta at the end of August and the rotifers groups Brachionus diversicornis, $B$. calyciflorus, Keratella tropica, Filinia longiseta in September with declining of number of species, reportea about high degree of organic pollution.

In general, in the ponds of the fishery farms, the trend of the saprobity curve tends to increase in values during the spring-summer period (May-June), decrease in the middle of the growing season in July and further increase in the autumn. The magnitude of the saprobity of the reservoir was influenced by both internal (the level of phytoplankton development, zooplankton ingestion by fish, succession changes), as well as external factors (precipitation, mineral and organic fertilizers). 
According to zooplankton indicative organisms, the level of organic contamination in the ponds corresponded periodically to the o- $\beta$ - and $\beta$ - $\alpha$-mesosaprobic degree, that is, the water of the studied reservoirs by the criterion of degree of purity varied from sufficiently pure to moderately polluted, by the criterion of trophism - from mesotrophic to polytrophic, by the state - from good to moderate good, in general, water by water quality categories belonged to the II-III class of water quality (Arsan et al., 2006). Parasitological examinations of carp yearlings in growing ponds of different farms in Lviv region revealed an invasion of ectoparasites by L. cyprinacea and D. vastator (Table 7).

Table 7: The incidence of carp this year by the ectoparasites of $L$. cyprinacea and $D$. vastator in ponds in Lviv region $(n=20)$

\begin{tabular}{|c|c|c|c|c|c|c|c|}
\hline \multirow[t]{2}{*}{ Fish farm } & \multirow[t]{2}{*}{ Months } & \multicolumn{2}{|c|}{ L. cyprinacea } & \multicolumn{2}{|c|}{ D. vastator } & \multicolumn{2}{|c|}{$\begin{array}{l}\text { Mixed infestation } \\
\text { L. cyprinacea / } \\
\text { D. vastator }\end{array}$} \\
\hline & & EI, \% & II, units & EI, \% & II, units & EI, \% & II, units \\
\hline \multirow{3}{*}{ «Stryi» } & July & 30 & 2.50 & 25 & 6.20 & 30 & $2.83 / 11.33$ \\
\hline & August & 25 & 2.60 & 20 & 4.50 & 20 & $1.75 / 7.25$ \\
\hline & September & 15 & 1.67 & - & - & - & - \\
\hline \multirow{3}{*}{ «Rydnyky» } & July & - & - & 50 & 11.40 & - & - \\
\hline & August & - & - & 40 & 9.75 & - & - \\
\hline & September & - & - & 25 & 4.20 & - & - \\
\hline \multirow{3}{*}{ «Khodoriv» } & July & 20 & 2.50 & 25 & 11.60 & 35 & $2.40 / 7.71$ \\
\hline & August & 15 & 2.33 & 15 & 9.33 & 20 & $2.25 / 6.75$ \\
\hline & September & - & - & 10 & 4.50 & - & - \\
\hline \multirow{3}{*}{$\begin{array}{l}\text { «Velykyi } \\
\text { Lyubin» }\end{array}$} & July & 35 & 3.43 & - & - & - & - \\
\hline & August & 25 & 2.60 & - & - & - & - \\
\hline & September & 10 & 2.50 & - & - & - & - \\
\hline
\end{tabular}

Studies of ponds in Stryi fisheries during the first month of monitoring (July) showed that they were invaded by lernae with an infestation intensity of $30 \%$ and an intensity of 2.50 individuals. The magnitude of invasions of fish by lernae in August and September decreased slightly - by 5 and 15\%, respectively; In August II grew by $3.8 \%$ and in September decreased by $33.2 \%$; the average EI in the pond was $23 \%$, the average II - 2.26 ind.

The extent invasion of carp yearlings by dactylogyruses in July was $25 \%$, II 6.20 ind. In August, the EI of fish by D. vastator decreased by $5 \%$, and of the II by $27.4 \%$. In September, no ectoparasites were detected on fish gills. The average EI during the growing season in the pond was $23 \%$, the average II - 5.35 ind. At the same time, some carp yearlings have shown a mixed invasion by $L$. cyprinacea and D. vastator. 
During July, the EI was $30 \%$, the average of the II by lernae was 2.83 ind., by dactylogyruses - 11.33 ind. In the following period (August), EI decreased by $10 \%$, II by larnae and dactylogyruses by 38.2 and $36.0 \%$, respectively. In September, no associative invasion of ectoparasites was detected this year. The average EI during the growing season in the growing pond was 25\%, the average II by lernaea -2.29 ind. and by dactylogyruses -9.29 ind.

During the study period, only monoinvasion of carp yearlings by ectoparasite was established in the cultivation pond of the fishery "Rudniki": in July, 50\% of the fish were invaded with an average of 11.40 ind., during the second month (August) the extent and intensity of the invasion (EI - 10\%, II - 14.5\%) was recorded. 5 individuals (25\%) of the surveyed carp yearlings were affected with intensity 4.2 ind. in the fall (September). The average EI for fish growing in the pond during the growing season was 38\%, and II - 8.45 ind. In the «Khodoriv» fishery growing pond, EI of carp yearlings by lernaea was $20 \%$, II - 2.50 ind. In August, EI and II values went down for 5\% and 6.8\%, respectively. In September, carp yearlings were free of ectoparasites. The average EI during the growing season in the growing pond was $17 \%$, the average II -2.42 ind.

According to the results of a parasitological study, it was found that in carp yearlings the EI by D. vastator was $25 \%$ in July, and II - 11.60 ind. In August-September, the EI of fish with dactylogyruses decreased by 10 and $15 \%$, and the intensity by 19.6 and $61.2 \%$, respectively. The average EI during the growing season in the growing pond was $17 \%$, the average II - 8.48 ind.

A mixed invasion of L. cyprinacea and D. vastator was detected in 35\% of carp yearlings in July, with an average of II by lernaea of 2.40 ind., by dactylogyruses of 7.71 ind. In August, the extent of associative invasion was reduced by 15\%, the incidence of lernaea invasion by 6.2 , and dactylogyruses by $12.3 \%$. The average EI during the growing season in the growing pond was $28 \%$, the average II by lernaea -2.33 ind., by dactylogyruses - 7.23 ind.

Research in the growing pond of the "Velykyi Lyubin" established monoinvasion of carp by lernaea: in July EI of fish was 35\%, II - 3.43 ind.; in August, EI of fish by L.cyprinacea decreased by $10 \%$, II - by $24.2 \%$, in September EI decreased to $10 \%$, II to 2.50 ind. The average invasion intensity in the growing pond during the survey period was $23 \%$, the average invasion intensity was 2.84 ind.

Thus, in the growing ponds of fishery farms in the Lviv region, the invasiveness of carp yearlings by the ectoparasites $L$. cyprinacea and $D$. vastator was established. Diseases were recorded by one or the other being mono or associative invasions. The course of invasions and the degree of invasiveness of fish by ectoparasites was different at other farms. The most intense damage of carp yearlings to by ectoparasites in growing ponds is during the period of July-August. 


\section{CONCLUSION}

In the surveyed reservoirs of fisheries, 76 taxonomic units of zooplankton represented by rotifers (Rotatoria) and lower crustaceans (Cladocera, Copepoda) were identified. The dominant zooplankton complex was dominated by representatives of the genera Asplanchna, Brachionus (Rotatoria), Ceriodaphnia, Daphnia (Cladocera), Acanthocyclops, Eudiaptomus (Copepoda). The average seasonal zooplankton biomass ranged from $6.08-9.95 \mathrm{~g} / \mathrm{m}^{3}$. The basis of phytoplankton was formed by green, diatomic, euglenic and blue-green algae with predominance of species of the genera Scenedesmus, Euglena, Navicula, Pediastrum, Peridinium, Oscillatoria, Microcystis. The average seasonal values of phytoplankton biomass ranged from $4.69-13.86 \mathrm{mg} / \mathrm{dm}^{3}$. The zoobenthos of the studied reservoirs was represented by chironomidae larvae and oligochaetes. The average seasonal rates of zoobenthos biomass in farm ponds ranged from 1.74 to $1.92 \mathrm{~g} / \mathrm{m}^{2}$. In general, the indicators of quantitative development of the components of the natural forage base met the standards for the growing ponds of the region and, as we believe, were not a brake factor for the development and growth of the fish under study.

According to the results of the epizootic monitoring in the fish farms of the Lviv region, the invasiveness of the carp by ectoparasites Lernaea cyprinacea and Dactylogyrus vastator is established. The disease was recorded as mono- and associative invasions. The extensiveness of the invasion of the carp yearlings by lernae in the growing ponds was $10-35 \%$ (intensity of invasion $-1.67-3.43 \mathrm{sp}$.), by dactylogyruses - 10-50\% (II - 4.2-11.6 sp.). Mixed invasion L. cyprinacea and D. vastator are found in $20-35 \%$ of carp yearlings (II lernaea $-1.75-2.83$ sp., dactylogyruses $-6.75-11.33$ sp.). The highest invasibility of yearlings carp with ectoparasites in the ponds was established during July-August.

\section{REFERENCES}

Abakumov, V.A. (1983). Guidelines for hydrobiological analysis of surface waters and bottom sediments. Hydrometizdate, Leningrad.

Abdullaev, H.G. (2011). The spread of crustacea among fish in Azerbaijan. West. innov. Evraz. Univer., 3: 116-120.

Arsan, O.; Davidov, O. and Dyachenko, T. (2006). Methods of hydro-ecological studies of surface waters. Logos, Kiev.

Balushkina, E.V. and Vinberg, G.G. (1979). The relationship between the length and body weight of planktonic crustaceans. Experimental and field studies of the biological foundations of lake productivity. Leningrad. The science. pp. 58-72. 
Bauer, O.N. (1987). The determinant of parasites of freshwater fish of the fauna of the USSR. Nauka, Leningrad.

Beliba, V.G. (2006). Parasitofauna of the rib of natural and piece waters of the Kharkiv region. Veterinary medicine, 86: 30-39.

Benovics, M.; Desdevises, Y. and Šimková, A. (2017). Dactylogyrus (Monogenea) parasitizing cyprinids from Balkan Peninsula: phylogeny and relationships to central European species. In: 8th International Symposium on Monogenea, 6-11 August 2017, Brno, Czech Republic, 37 pp.

Bykhovskaya-Pavlovskaya, E.I. (1985). Fish parasites. Study guide. Leningrad. The science.

Chislenko, L.L. (1968). Nomograms for determining the weight of aquatic organisms by size and body shape. Moscow, $97 \mathrm{pp}$.

Gemmerday, O.V. (2010). Invasions of freshwater fish in the reservoirs of southern Ukraine. Scientific Bulletin of NULES of Ukraine, 151(2): 80-83.

Golzio, J.E.S.A; Falkenberg, J.M.; Praxedes, R.C.G.; Coutinho, A.S.; Laurindo, M.K.; Pessanha, A.; Madi, R.R.; Patrício, J.; Vendel, A.L.; Souza, G.T. R.; Melo, C.M. and Lacerda, A.C.F. (2017). Gill parasites of fish from two estuaries in northeastern Brazil: new hosts and geographical records. Anais Da Academia Brasileira De Ciências, 89(3): 2281-2291.

Hemaprasanth, A.; Singh, R.; Raghavendra, A.; Sridhar, N.; Raghunath, M.R. and Eknath, A.E. (2011). Comparative susceptibility of carp fingerlings to Lernaea cyprinacea infection. Vet. Parasitol., 178(1-2): 156-162.

Hossain, M.; Ferdoushi, J. and Rupom, A.H. (2018). Biology of anchor worms (Lernaea cyprinacea). J. Entomol. Zool. St., 6(1): 910-917.

Jmil, V.I. and Jmil, O.M. (2010). Epizootic well-being in relation to monogenic carnivorous fish in central Ukraine. Scientific Bulletin of Veterinary Medicine, 3(73): 30-32.

Kiselov, I.A. (1969). Plankton seas and continental waters. 1. Leningrad, the science. $657 \mathrm{pp}$.

Kutikova, L.A. (1970). Rotifers of the fauna of the USSR. Moscow. The science. $744 \mathrm{pp}$.

Loboiko, Y.V. (2012). The infestation of carp this year by the ectoparasites Lernaea cyprinacea and Dactylogyrus vastator in growing joints. Veterinary biotechnology, 21: 286-290. 
Manuylova, E.F. (1964). Cladocera (Cladocera) fauna of the USSR. Moscow. The science. 327 pp.

Mazur, T.V.; Sorokina, N.H.; Halchynska, O.K.; Novhorodova, O. and Oliinyk, O.B. (2011). The epizootic situation of infectious fish diseases in Ukraine. NUBiP Scientific Reports, 5(27): 5-11.

Monchenko, V.I. (1974). Fauna of Ukraine. 27. (3). Cyclops : Scientific thought. $452 \mathrm{pp}$.

Nitta, M. and Nagasawa, K. (2017). Monogenean fauna of Japanese freshwater fishes and phylogeny of Dactylogyridae from Japan. 8th International Symposium on Monogenea, 6-11 August 2017, Brno, Czech Republic.

Pukalo, P.E. (2006). Epizootic condition and parasitological situation in the fishery farm "Yaniv" (OJSC "Lviv oblribkombinat"). Bulletin of the University of Lviv, 42: 8488.

Rastiannasab, A.; Hemmatzadeh, M.; Khara, H. and Saljoghi, Z.S. (2016). Changes of haematological indices of grass carp, Ctenopharyngodon idella exposed to monogenean parasites, Gyrodactylus spp. and Dactylogyrus spp. J. Parasit. Dis., 40(3): 627-629.

Sladeček V. (1973). System of water quality from biological point of view. Stuttgart. Ergebn. Limnol, 7, 218 pp.

Sörensen, T. (1948). A method of establishing groups of equal of amplitude in plant sociology. Kgl. Dansk. Vidensk. Selsk., 5(4): 1-34.

Vinberg, G.G. and Lavrentieva, G.M. (1982). Guidelines for the collection and processing of materials in hydrobiological studies in freshwater bodies. Zooplankton and its products. Leningrad. $35 \mathrm{pp}$.

Vovk, N.I. (2002). The most widespread diseases of fishes during cultivation in ecological conditions of fisheries of Ukraine. Scientific works of Poltava SAS, 2(21): 150-151.

Yevtushenko, I.D. (2013). The epizootic situation of fish parasites in water bodies of Kharkiv region. Veterinary medicine, 97: 180-190. 